\title{
15. ハイビジョンの産業応用
}

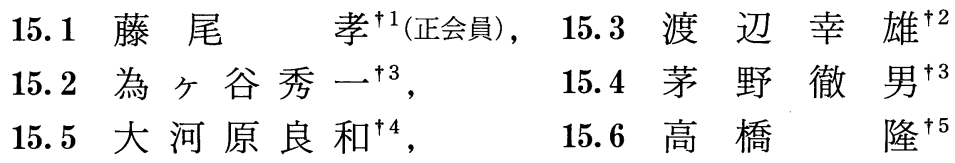

\section{1 ま がき}

電子画像システムは, 画像の加工や処理をはじめ, 記録や伝送などが，すべて画像データの処理によって できるという, フィルムや紙など他の画像メディアに ない優れた特徴を持っている。このため, ハイビジョ ン技術の開発と並行して, 1980 年代からこれを映画 や印刷, さらに医療など, 広い画像産業の分野に取り 入れようという試みがなされてきた。そして今，これ らの多くが試行の段階を終え, 実用期を迎えようとし ている.

（藤尾）

\section{2 映像ソフトの制作}

ハイビジョン制作機器の開発・充実が進む中で，ハ イビジョン MUSE ディスクによる映画ソフトの販売 が始まるなどの昨今の情勢から, 映画やハイビジョン $\mathrm{CG}$ 分野での映像ソフト制作もディジタル映像処理の 進展により着実に広がってきている。

\subsection{1 映画制作}

毎年米国で開催される SIGGRAPH の 1993 年の最 大の話題は, スピルバーグ監督の「ジュラシック・パ ーク」の CGであった。ここで利用されている技術は ハイビジョン CGではないが，これまでのCGにおけ る表現の限界を取り除き, CG で表現できないものは

\footnotetext{
$\dagger 1$ 松下電器産業株式会社

†2 国際メディアコーポレーション

$\dagger 3$ NHK エンジニアリングサービス

$\dagger 4$ 凸版印刷株式会社

$\dagger 5$ 京都大学 医学部

"14. Applications of HDTV" by Takashi Fujio (Matsushita Electric Industrial Co., Ltd., Osaka), Yukio Watanabe (International Media Corporation, Tokyo), Shuichi Tamegaya and Tetsuo Chino (NHK Engineering Service, Tokyo), Yoshikazu Okawara (Toppan Printing Co., Ltd, Tokyo) and Takashi Takahashi (Faculty of Medicine, Kyoto University, Kyoto)
}

ないことを実証した。まさに映画制作において CGが 不可欠な表現技術となったこと，そして制作コストが 映画制作において見合うものになってきたことを証明 したものといえる．

これより少し前に公開されたハリウッド映画「スー パー・マリオブラザーズ」の, クライマックスシーン における恐竜の映像は, ハイビジョン CGで制作し, この映像イメージをコンピュータデータよりフィルム に変換している.八イビジョンにおけるディジタル映 像技術の応用は, フィルムの世界におけるオプティカ ル処理では充分なクオリティが得られなかった, マル チレイヤの映像制作に大きく寄与している.

ハイビジョンをコンピュータシステムと結合し，デ イジタル処理を図ることにより, 映像処理, 画像合成 などの映像イメージ創造とともに, モーションコント ロールカメラやマット合成による効果的・効率的な映 像制作が可能になってきた，国内でも大林宣彦監督に よる「水の旅人」での小さな武士の合成に，ハイビジ ヨンクロマキーが巧みに利用されている。また, 市川 昆監督による「その木戸を通って」は, ハイビジョン CCD カメラの性能をいかんなく活かしたハイビジョ ン映画ともいえ, フィルムに変換されてベネチア国際 映画祭でも上映されている.

ハイビジョンの映画制作への応用も，電子技術の画 像加工性, 処理性を活かし, Hi-Vision intermediate と呼ばれているもののように，フィルムと電子映像 各々の特徵を活かした融合型の制作手法が映画界で定 着しつつある。

\subsection{2 ハイビジョン CG}

1992 年より, SIGGRAPH のメインイベント/エレ クトロニックシアターにおける公式上映システムとな ったハイビジョンシステムにより, 毎年各国で制作さ れたハイビジョン CG 作品が, ハイビジョンディジタ ルVTR およびハイビジョンプロジェクタで直接上映 
されるようになっている．

八イビジョンシステムによる CG 映像の直接上映 は, 従来フィルムに変換して上映するしかできなかっ た高精細な CG 作品が，明るくなってきたハイビジョ ンプロジェクタによって，その映像の質を下げること なく上映できるようになったことを，近年 CG 映画関 係参加者に強く印象づけてきている。また，1993 年 は「Stereoscopic HDTV Room」と呼ばれる特設の 偏光グラスによる立体ハイビジョン上映設備が設けら れ, GOKU (Magic Box Production), STEREOSAURUS (HD/cg, New York), Mongol(大成建 設)等の立体ハイビジョン CGにより $3 \mathrm{D}$ 作品が上映 された。ハイビジョンCG による立体映像は，その高 精細性と共に立体感が素晴しく, 従来多くは大型の映 像館でしか見られなかった立体映像の利用範囲を，大 きく広げる可能性を示していた。

一方, パソコンとハイビジョンの結合によるペイン トシステムにより，「銀河の魚」のようなセルアニメ ーションの世界にも新しい映像表現領域を広げてい る。ハイビジョンがコンピュータシステムと結合する ことによりメディア間の障壁が乗り越えられ，マルチ メディアが大きく進展していくものといえる.

景観シミュレーションや医療応用, ライダーシミュ レータなど, 大きく広がって来ているハイビジョン CG ソフト制作需要に対して, ハイビジョンソフトビ ジネス養成塾等により, ハイビジョン映像制作を志す ソフト制作者の育成も積極的に行われ始めた。

\subsection{3 ハイビジョン映像祭}

ハイビジョン, HDTV 技術システムの実用化に伴 い，世界的レベルで新しい映像ソフトの制作が広が
り，国際エレクトロニクス・シネマ・フェスティバル (IECF) として, これら作品のコンテストも行われて いる.

この機関は 1987 年に始まり, 最近は奇数年(西暦) がスイスのモントルー市, 偶数年が日本で開かれ, 年 間の参加作品が 100 タイトル近くにもなってきてい る. 今年は通算 7 回目で, 名称も「ハイビジョン国際 映像祭(日本語名)」として，6月 7 日から 1 週間, 千葉市 の幕張コンベンションホールで開催されたが, 新しい 世代に向けた電子映像技術による映像ソフト制作の幅 広い可能性と，促進策が図られている。

(為ヶ谷)

\section{3 ハイビジョン表示産業}

ハイビジョンディスプレイの導入状況から産業応用 の利用の推移をみると, 1988 年までの 10 施設程度が 1989 年から毎年 25 程度, 1992 年には約 70 と飛躍し, 1993 年末に総計は 170 を越えている.

図 1 が 1993 年末における表示産業の利用分野と規 模を示したもので, その利用状況の傾向は美術館や博 物館などのギャラリー型は 40〜 50 人程度の設置規模 で，明室での鑑賞という視聴環境条件から 110 120 インチ級のリアタイプに集中している. シアター型は 設置条件と画面の明るさの確保から 200 インチ級まで が多い.

\subsection{1 シアター}

映画産業とハイビジョンとの融合については, つく ば万博(1985)の頃からハードやソフト, 運用と経済性 など多角的に検討されてきている. 最近では大型ディ スプレイも明るい型に改善され, ILA (Image Light Amplifier) と呼ばれる光増幅型の新機種の開発も行わ

(フロント投射方式)

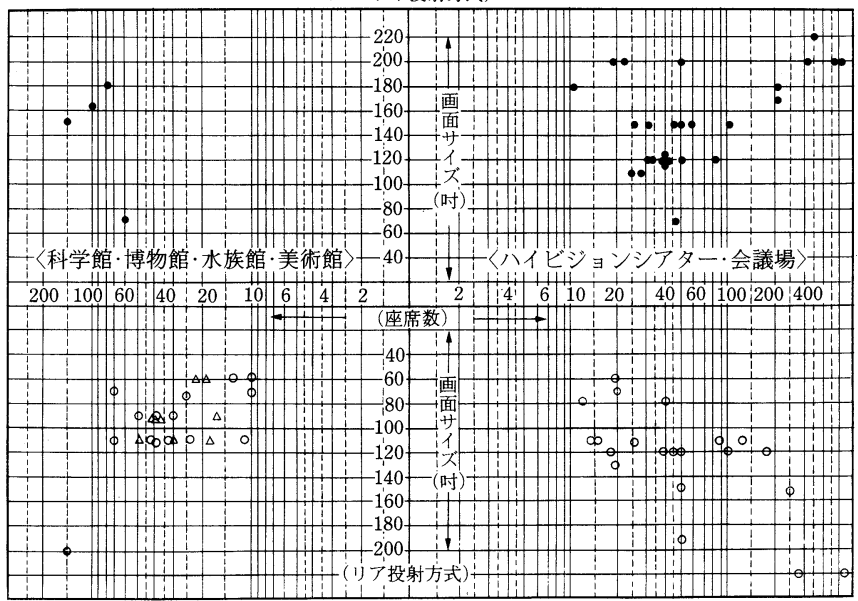

図 1 ハイビジョン表示産業の利用分野と規模 
れている. 1993 年には映画館でのハイビジョン上映 の事例がいくつか見られた．

有料では, ハイビジョンフェス夕(1992 までは東京 国際映画祭の併設イベント)でのハイビジョン映画の 上映と, Jリーグのサッカー競技場からの衛星中継 (CS) による競技実況の受信上映である.また, 皇太 子ご成婚の模様を衛星放送(BS)のハイビジョン試験 放送から受信, 地域住民にサービス上映をした。

1993 年には, 競輪場としては初めてハイビジョン カメラとVTR を備えて実況中継できるシアター $(120$ インチリアタイプ)が常設された.

このように, 画像情報の電子配信というフィルムに ない大きな特徴が加わり, ソフト源は映画だけでなく ライブのスポーツ, 音楽, 演劇, オペラやご成婚, オ リンピックなどの歴史的イベントに及び, 従来の映画 興行の概念を変えさせるものを持っている.

会議場, 文化センター, 学習センター等でも大型デ イスプレイ(200〜250インチ級)が常設され, 会議の パネルとなり, 学習の教材展示ボードとなり, シアタ 一のスクリーンとなる。 その利用目的からリアタイプ の設置が多い.

\section{3.2 ギャラリー}

1989 年に美術館に初めてハイビジョンギャラリー が導入され, その 60〜110 インチ級の高品質の静止画 像は専門家にもショックを与えた。 それ以来, 八イビ ジョンは新しい表示産業のひとつとして定着し, 移動 型のギャラリーなど新分野を拓くとともに, 今後の高 齢化社会に大きく貢献することになろう.

1990 年代に入ってから相次いで美術館, 科学館, 動物園, 水族館, そしてビジネススペースにギャラリ ータイプのハイビジョンシステムが常設された.

これらのシステムで特徴的な点は, 観客が選択でき る参加型とし, データベースの検索やゲーム性を取り 入れたり, 手づくりのソフト制作ができるなど, 新し いシステムを構築しているものが多い.

ハイビジョンの 2 眼式立体表示システム(以下 $3 \mathrm{D}$ という)も早くから実験検討されている. 常設として は 1990 年に時分割式 $3 \mathrm{D}$ の実用化実験装置(つくばコ ズミックホール, 400 インチリア型)がある. 1992 年に 水族館 (東海大学)にフロント投射型 (150 インチ級)の $3 \mathrm{D}, 1993$ 年には, 動物園にリア投射型(110 インチ 級)の $3 \mathrm{D}$ が設置運用された。いずれも偏光分離式で ある。

1992 年, ハイビジョンでの眼鏡なし 3 D が研究公 開された. 実用化が期待される.NTSC方式では 1993 年に実用機の製品発表が行われた.

\section{3.3 空間展示}

空港や駅，デパートのロビーのように多くの人が集 散し, 明るく展示スペースも小さい場所では, 多様な 情報が表示できる積み重ね式のマルチ画面が使われ る。

1992 年から成田など空港に 12 面マルチが常設され た. 1993 年にはシンガポールのデパートの広場に 24 面マルチ画像システムが常設された。ここでは PAL, NTSC, ハイビジョンなど多様な映像ソフトを展開す る国外では初めての展示空間となった．

表示機器の課題は画面の大型化, 高輝度化と省スぺ 一ス化であり,さらに早くから望まれている中小型の 平面型ディスプレイの実用化である. またマルチメデ イア時代に対応する機能と性能も求められ, 従来のス ライドや OHP に頼らない光ディスクや $\mathrm{CD}$ などと組 合せた電子映像によるペーパレスプレゼンテーション システムも開発実用されてきている.

最近は，また八イビジョンの大型ディスプレイで多 人数の人々が楽しむテレビゲームも出現してきてい る。

(渡辺)

\section{4 ハイビジョン静止画応用}

岐阜県美術館等にハイビジョンギャラリーが初めて 導入されてからこの約 5 年間に, 静止画によるハイビ ジョン産業応用は目覚ましく進展し, 八イビジョン応 用の代表的分野のひとつに成長した。

特に 1992 年からは, 機器(展示型ハイビジョン静止 画ディスクシステム)の互換性を確保する技術ガイド ラインの策定(ハイビジョン普及支援センター： HVC, 1991 年), 美術作品を中心とする市販ソフト 制作の活発化あるいは機器導入に関わる経費助成措置 等, ハイビジョン利用を促す環境が整ったこともあっ て, 静止画システムを導入する公共団体, 民間企業等 が急激に増加した。なかでも，公共団体等が設置した 美術作品鑑賞を主な目的とするハイビジョンミュージ アムは, 1991 年末に 10 施設余りであったものが, 1994 年頭初では 60 施設を越えている.

最近の動向から見ると, ハイビジョン静止画応用は 今後, 検索等システム機能の多様化あるいは動画等も 扱うマルチメディア化等が進み，応用分野も美術界だ けでなく様々に広がる中で, 一層発展していくことが 予想される。

\subsection{1 応用分野の広がり}

ハイビジョン静止画応用の進展には, 地方公共団体 が文化面から推進する地域振興施策に対して, ハイビ ジョンが有効な手段を提供できたことが大きい．その 


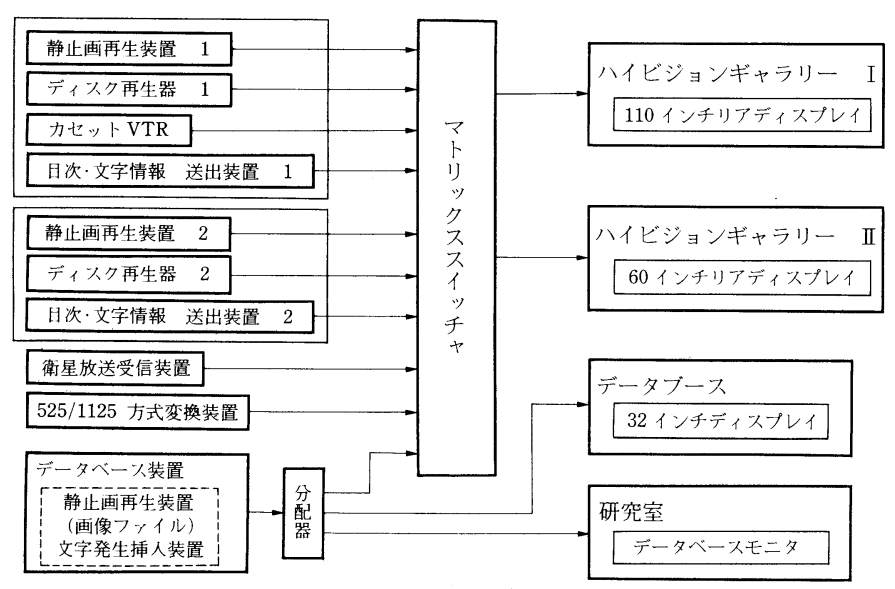

図 2 ハイビジョンギャラリーシステム構成例

手段, 八イビジョンギャラリーは, 八イビジョン静止 画の優れた特質を生かし，まず美術作品の鑑賞に利用 されて普及の原動力となった。それがきっかけで利用 が進展し, その進展がまた新しい利用を産み出す形で 年毎に応用分野は多様化してきている。最近では建築 家の作品展示 ${ }^{11}$ や写真家の作品を専門に鑑賞する施 設2)も登場した。また，美術鑑賞だけでなく，地域の 自然や文化・歴史・産業などについての理解を深める ための利用が, 美術館はもとより自治体庁舎, 生涯学 習センター, 図書館, 科学館等を拠点に進んでい る3). 広報などを静止画システムで実施する自治体も 登場している. 公共分野以外では, 企業, メーカー等 のギャラリー, ショールーム等にシステムの導入が進 んでいる.

このように静止画応用が多角的に展開する中で, シ ステムも一層多様化している. 図 2 に最近のハイビジ ヨンギャラリーシステム構成例を示す．

静止画応用におけるソフトは年を追って充実してき ている ${ }^{3)}$. 美術館等のいわゆる自館ソフトあるいは地 域独自ソフトの蓄積が進む一方で, 「19 世紀フランス 美術の世界」シリーズや「世界美術館」シリーズ等の 市販ソフトも, 新しいタイトルが着実に増え, 市場が 見えつつある．また，簡易な制作装置を用いてユーザ 一が制作する，いわゆる手作りソフトも各地で行わ れ，専門家と違った味を出している。

\subsection{2 検索型(データベース型)への展開}

静止画システムでは, 画像は素材の形でディスクに 記録されているので, そのまま画像データベースでも ある。したがって，それらの画像に対応する属性情報 (検索の条件となるキーワード等)を与えれば，いわゆ る検索型データベースが構成できる，そのため当初か
ら検索型システムへの関心は高く，すでに幾つかの美 術館等に導入4) 6) されているが, 一般の人久の鑑賞と 学芸員等専門家の研究の両面で利用の可能性が注目さ れている. 1992 年に開催された「文化財の画像デー夕 ベース研究一岐阜会議」では, 検索型システムの事例 報告も行われ，今後への期待が語られた。

また, HVCは, 教育用医学画像データベースシス テムに関する調査研究を 1992 年に実施, その有用性, 可能性を確認し,さらに 1993 年度, 1 万フレーム規 模のハイビジョンデータベースを教育に使う, 医学教 育システム7)を開発した。

静止画像は本質的にデータベース向きの情報であ り, 静止画応用は検索型システムによって一層幅広い 分野で利用されていくものと考光られている。 そのた め, HVCでは, 検索型システムに関わる技術ガイド ラインを 1993 年度内にも策定すべく審議を進めてい る.

検索型システムのさらなる発展のひとつの方向であ るハイビジョンマルチメディアへの試みも注目されて いる．静止画に加えてハイビジョン動画，NTSC 動 画，それにテキスト情報等をマルチに使用し，豊かな 表現, 多様な利用を可能とするもので, システム面で はハイビジョンマルチメディアデータベースの研究, またソフト面ではハイパーハイビジョン風土記の制作 などの例がある．また，同じ技術基盤に立つハイビジ ヨン電子出版でもイメージソフト制作など研究が行わ れている.

(茅野)

\section{5 電子印刷・電子出版}

\subsection{1 情報処理の電子化}

印刷会社は印刷(静止画像)を主体とした情報処理を 
本業とした業務を行ってきているが，ここ十数年で急 速に電子化，ディジタル化してきている．

文字は長い活字の時代, 写真植字を経て, 1970 年 頃からはCTS(コンピュータライズドタイプセッティ ング)が実用化. 1970 年代後半からカラー製版にトー タルスキャナが導入されて画像処理技術が飛躍的に進 展. 1980 年には従来からのフィルム原稿に加えてテ レビ(ビデオ)映像からのビデオ製版の開発. 1983 年 には CG データ (ディジタル信号) からの直接製版の開 発. 1986 年にハイビジョン映像の 1 フレーム情報を ディジタル化した直接製版・印刷する技術を開発した。 さらに, 製版工程を使ってのハイビジョン静止画変 換, 音声と映像のディジタル処理への対応を広め, 紙 以外の CD-ROM をはじめ CD-I, MO などの電子媒 体にまで業務を拡げてきた。印刷分野も情報メディア のディジタル化に伴い, 音声や動画を含むマルチメデ イア対応の世代に入っている。これによりトータルデ イジタル対応の体勢が整いつつある。

\subsection{2 印刷変換系}

電子情報を印刷システムにインタフェースするため の印刷変換としては, 階調変換 $(\gamma$ 補正 $)$ と色変換が必 要で, さらにこの変換工程でビデオ系特有の色ずれ, ランダムノイズ, 太い画像輪郭, リンギングなどの画 像修復処理を施す。このうち色変換は, 両カラーメデ イア間の表色系(蛍光体と印刷インキ)や混色方法の違 いを補正するもので, 最も複雑でビデオ印刷のキーと なる技術分野である。そしてハイビジョン映像を通常 の印刷物のように 12 画素 $/ \mathrm{mm}$ で出力すると $9 \times 16$ $\mathrm{cm}$ になる。これ以上の大きさが必要な場合は補間処 理を施す. 最後に製版スキャナにより直接網ポジ 4 版 に出力して, 印刷物とする。

ハイビジョン印刷の実用化の一例として，ビデオ映 像素材を検索するため約 18000 フレームの映像を変換 した画像を載せたカタログ「高画質ビデオ素材ライブ ラリー」など, 双方のメディアの特徵を生かしたもの

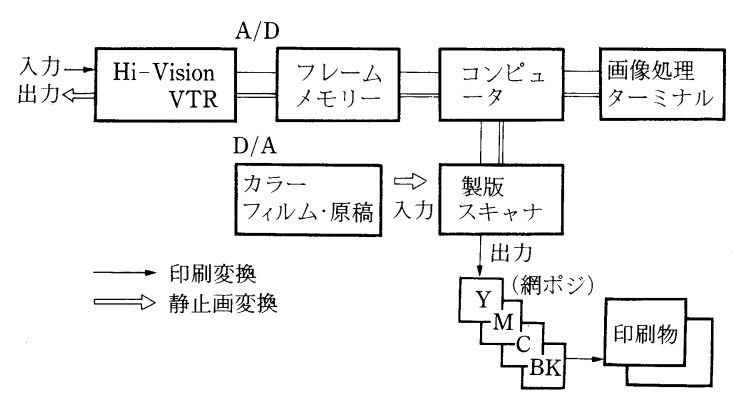

図 3 ディジタル画像処理システム
などが実用化されている. しかし, 従来のフィルム系を 素材としたものに比べると, 画質の問題, コスト, 八 イビジョン自体の実用化との関係などの問題を抱えて おり，多くの実用例を見るまでには至っていない.

\subsection{3 ハイビジョン静止画入力系}

八イビジョン静止画は 1 画面の提示時間が長く, 凝 視されるため, 1 画面あたりの情報量はテレビの動画 に比べ数倍から 10 数倍必要とされる.したがって, 高解像度, 高い $S / N$, 広いダイナミックレンジが要 求される。このような条件を満たす情報の入力系とし て, 製版用スキャナが活用され, 高 $S / N$ で, 高画質 の静止画情報を得ている。このスキャナで変換した静 止画情報は, 画像の加工処理, 階調補正や色変換を行 って, 高精細画像データベースとする。このデータレ ートをハイビジョン規格のものに変換し，広いハイビ ジョン産業に供給する．現在このような方法で印刷分 野とハイビジョン産業を結びつけ，美術・芸術や放射 線などの大型医療画像がハイビジョン端末上に検索， 表示されるようになっている。このような両分野間の データが結びついた結果, 今後, 双方の特徵を活かし たマルチメディア展開が可能となってきた。

貴重な文化遺産を記録したフィルムも時間が経過す ると劣化する．このカラーフィルムを画像補正・色変 換・画像合成などの処理をして, 高画質のディジタル データベース化，これからハイビジョン静止画ソフト 制作，豪華美術本出版などを行っている ${ }^{9)}$.

\subsection{4 広がる応用展開}

\section{(1) 印 刷}

ハイビジョンは放送メディアとして速報性，機動性 を発揮する. NTSC の現行放送もしばしば，突発事 件の報道に利用されている。 ハイビジョン放送からオ リンピックの開会式，競技シーンなどが雑誌・新聞の カラー頁に応用されている。花博では会場内の八イビ ジョン放映から「ハイビジョングラフ」が 183 日間連 日発行され注目を集めた。この他に，出版としては八 イビジョンソフトから「写真集」,「CG 絵本」,「CD 音 声付き絵本」などが出版されている。これらはいずれ もハイビジョンソフトと連動したメディアミックスと して, ハイビジョンの高画質, CG とのビデオ合成, PCM の高音質といったハイビジョンの特性を引き出 したものとなっている．顕微鏡下の脳外科手術シー ン, 数百倍に拡大された微生物・科学反応など, 今ま で司くことのできなかったミクロの世界を安価な印刷 物にすることで，誰でも見ることが可能となった．

（2）電子媒体・マルチメディア展開

美術館ハイビジョン静止画が共通システムとして実 
用に入っているのをはじめとして, ハイビジョンソフ 卜から変換されて各種の電子媒体に変換, 応用され始 めている。ハイビジョンは高精細に加えて高音質の特 性を持っている。この特性を生かしたビデオ，LDな どの商品が販売されている。 またワンソースからの展 開として, カラーフィルムをディジタル処理/データ ベース化して豪華美術本と静止画ソフトのシリーズと して展開した例や, ハイビジョン LD で動画を観賞し, 絵本を見て, CD-ROM で必要な項目を検索する試み も始まっている.

(大河原)

\section{6 医学・医療分野への応用}

医学分野への電子映像の特徴を活かした, ハイビジ ヨンシステムの導入は, 早い時期から取り組まれてき $た^{10)}$. 本項では, その後の医療応用の現状を, 医療に 関連する社会的催し, 医学学術集会における展示など の応用事例，および日常医療活動における応用事例な どについて, その概要を述べる.

\subsection{1 ハイビジョンビッグバン}

まず社会的催しとしては, 1990 年の花博以来, 毎 年秋に繰り広げられる「ハイビジョンビッグバン」が, 1992 年には’92 メディカルフォーラムとして企画さ れ ${ }^{11)}$, 幾つかの催しが開かれた。

そのひとつとしてハイビジョン放送による討論会 「医療の地域格差の是正とハイビジョン」が開催され, 遠隔医療に従事する多くの医師達が参加し, 映像通信 の重要さを述べるとともに, ハイビジョンへの熱い期 待が語られた。

また自治医大でも同分院大宮総合医療センターとの 間を通信衛星を介して結び, テレコンサルテーション や卒後教育の実験を行った.

\section{6 .2 学会，国際シンポジウム}

次に, 医学学術集会における応用事例では, 前報で も述べたように 1992 年 4 月に開催された第 23 回日本 医学会総会医療情報展示にて実演が行われ, 多くの病 理医によって高い評価を得たテレパソロジーが，国際 シンポジウム「テレパソロジーとハイビジョンの病理 診断学への応用」 ${ }^{12)}$ として取り上げられた。引続き第 81 回日本病理学会 ${ }^{13)}$ (仙台)においてもデモが行われ た.この実験では光ファイバによる非 MUSE のコン ポーネントハイビジョン情報の伝送で仙台市立病院と 会場を結んで行われた。

また, 日露医学医療交流第 1 回国際シンポジウム ${ }^{14}$ においても医学用ソフトウェアのデモが行われ，ロシ ア医療関係者に強い感銘を与えた。海外における学会 では,アジア太平洋がん学会においでApplication of HDTV International Cooperation in the Field of Healthcare”という課題でビデオセッションおよびサ テライトシンポジウムが行われた ${ }^{15)}$.

15.6.3 テレコンサルテーション

テレコンサルテーションを日常医療の一環として行 う例としては, 国立癌センターが先の国際シンポジウ ムでのデモに引き続いて同東病院との間で INS 1500 により定常的に病理診断を行っている.

また青森県立中央病院では, 県立中央病院が中心と なり秋田県下の地域医療機関国保大間病院と中核医療 機関むつ総合病院とをINS 64 で結び，X 線画像や患 者患部の画像を伝送, テレコンサルテーションを行 い, 地域との医療格差是正の可否を検討した.

\subsection{4 テレパソロジー}

これまでの医療応用ではテレパソロジー分野の事例 が集積されつつあり，評価も次第に固まりつつある. さらに臨床応用を目指した実験も開始されており, 山 形大医学部病理学教室 ${ }^{16)}$ では同大学病院手術室との 間に光ファイバによる病理画像伝送システムが設置さ れ, 術中迅速病理診断が実施されている。 また, 東北 大学に扔いても先の病理学会総会のデモ以降, 仙台市 立病院との間に光ケーブルを常設し, 病理診断 ${ }^{17)}$ 実施している.

テレパソロジーは，少ない病理医の偏在を補う目的 で実験が開始されたが，次第に判明したことは，当初 の目的に加元, 常にクリティカルな意思決定を迫られ る孤独な病理医がハイビジョンネットワークを通じて 同僚医師と相談することにより, より精度の高い診断 体制の確立が期待できるではないかということであ る。つまり，医療を補うことから医療を進める方向の ハイビジョン利用展開の可能性が示され，医療におけ る新しい映像文化の展開が期待されるところである.

\subsection{5 医学教育への応用}

ハイビジョンの医学教育応用として, 各種医学画像 の大容量で, 高速検索の性能を持つ画像データベース システムも開発された ${ }^{7}$.

この教育用データベースシステムは, ハイビジョン の画像規格で, 映像デー夕を約 $1 / 10$ に圧縮し，14 枚 の光ディスクにファイルする. 管理できるフレーム数 は 1 万枚で, これを臟器や病名などの属性や登録番号 により 2 秒以内で検索が可能である.

今後は医学を初め広い教育分野に応用されることに なろう。

(1994 年 3 月 22 日受付) 


\section{〔参 考 文 献〕}

1) 天野: CHROMA (Dec. 1991)

2） HVC 編：“奈良市写真美術館八イビジョンギャラリー”, HVCニュ 一ス No.27 (May 1993)

3）「ハイビジョン年鑑 1994 年版」編集委員会編：ハイビジョン年鑑 1994

4）国立西洋美術館：“国立西洋美術館主要絵画検索システム”，ART HI-VISION (同館パンフレット)

5） NEC 編：“愛知芸術文化センター芸術文化情報システム” NEC 技 報, 46, 6 (June 1993)

6）渡辺䚾：“新潟県立近代美術館のハイビジョンシステム” NHKES 誌, VIEW (Nov. 1993)

7）HVC, 機械システム振興協会：“高精細データベースに関する調査 研究”, 4-R-12 (Mar. 1993)

8）“ソニー高画質ビデオ素材ライブラリー”, ソニー株式会社 HD ソフ トセンター (Apr. 1993)

9）“敦煌”, NHK 放送出版協会（Apr. 1992）; “静止画ソフト・敦煌シ リーズ”, SMA リゾームサークル（1992〜1993）
10）藤尾ほか：“ハイビジョンの産業応用”, テレビ誌, 46, 7, pp. 895-901 (1992)

11）'92 メディカルフォーラム「医療の地域格差の是正とハイビジョン」, HVC NEWS, 23, (Sep. 1992)

12）日本学術会議病理学研連, 国際シンポジウム「テレパソロジーとハ イビジョンの病理診断学への応用」, 国立癌センター国際会議場 (Apr. 9, 1993)

13）第 81 回日本病理学会総会, ハイビジョンテレパソロジ・システム・ デモンストレーション, 仙台（May 14〜16, 1993）

14）日露医学医療交流財団, 日露医学医療協力機構, 第 1 回国際シンポ ジウム, 新潟（June 6〜11, 1993）

15）第 11 回アジア太平洋がん学会, Video Session and Satellite Symposium on "Application of HDTV International Cooperation in the Field of Healthcare" (Nov. 16 18, 1993)

16）荒井茂: “山形大学におけるハイビジョンテレパソロジー”, NEW MEDIA, 5, pp. 50-51 (1992)

17）大槻昌夫：“ハイビジョンテレパソロジー・システム一地域医療情報 システムの新しい試み”, 医療とコンピュータ, 別冊, 9, pp. 166-170 (1993) 